Journal Universitas Muhammadiyah Gresik Engineering, Social Science, and Health International Conference (UMGESHIC)

UMGCINMATIC : $1^{\text {st }}$ Rethinking Education during Covid-19 Era: Challange and Innovation

\title{
INTERNAL SUPERVISION MODEL WITH PROFESSIONAL LEARNING COMMUNITY TO DEVELOP BAN HUA FAI STUDENTS' BASIC WORDS READING AND WRITING BY USING 6-STEPS TEACHING TECHNIQUE
}

\author{
Author \\ Wuttichai Dana ${ }^{1}$ \\ Director of Ban Hua Fai School, Loei Primary Educational Service Area Office $2^{1}$ \\ wuttichaidana@gmail.com ${ }^{1}$
}

\begin{abstract}
ABSTRAK
The objectives of this research were 1) To develop learning management for Thai language subject by using 6-steps teaching technique, 2) to improve teachers' teaching and learning management with quality, 3) to improve students' reading and writing skills, and 4) to develop internal supervision to be strong continuously performed. The administrators and teachers of Ban Hua Fai School had the commitment to develop the students' learning to make them more competent in reading and writing since these skills are important foundation leading to learning other subjects. In addition, this is to operate in accordance with the policy of the Loei Primary Educational Service Area office 2 and the Office of the Basic Education Commission for driving educational innovation along with internal supervision by using the Professional Learning Community process to improve the higher quality of education. The results of the internal supervision using the Professional Learning Community process to improve the reading and writing of the students' basic vocabulary with the 6-steps teaching technique at Ban Hua Fai School.
\end{abstract}

Keywords: Learning Management, Student Learning, Teaching Technique

\section{INTRODUCTION}

Language is essential for communication. The elements of language are listening, speaking, reading and writing in order to help people in society to understand each other and live happily together. Teaching Thai for elementary level aims to develop students' language skills including listening, speaking, reading and writing, so that the students are able to communicate the perception and convey their thoughts and feelings to others. In addition, the importance of Thai language skill is being a foundation for learning other subjects. Reading is an important skill that enhances and expands the experience and provides a lot of enjoyment from books, documents, and publication media. At present, it is accepted that reading affects 
students' learning, namely, slow reading and incomprehensible reading, and unable to remember what was read would result in ineffective study results in that course as well. Reading is therefore essential to lead students to success in learning in various subjects. Moreover, reading will help students search for additional knowledge they want to know and expand their knowledge. Consequently, reading is a stepping stone to success in writing and others.

Writing is a more complicating than other skills, however, if you have good listening, speaking and reading skills, you will be able to convey comprehension, thoughts, and imagination in writing so that others can understand. Additionally, writing is also a tool that makes communication more retainable than any other language skills. Moreover, for writing, correct spelling does not only help readers understand more easily and faster, it can enhance the authors' confidence whenever they write. Basic words in each grade levels were classified into the basic word lists of each grade level. Each grade level has different word types, number of words, and difficulty levels for students. The words in the basic wordlist at each grade level are important for students to read and write. If students are able to read and write basic words at their grade levels, they will move on to the next level and the words they can read and write will be accumulated. After that, it is a step that students use basic words for learning various subjects themselves, and link to the use of words to develop their own learning.

Presently, a number of students at Ban Hua Fai School have learning disabilities in reading and writing. The students' reading behaviors are slow reading, mispronunciation, wrong intonation, and spelling while reading. For wring, students are slow to write, placing vowels and tones in incorrect positions, and alternating letters. These are the reasons why students are not successful in their studies. 6-steps teaching technique is an innovative or effective method for solving the problem of illiterate students designed by Sirilak Chompookham, a teacher at Ban Hin Lad School, Muang District, Maha Sarakham Province. She developed a 6-step process of teaching designed for students to be literate. The highlight is that each step is divided into steps from easy to difficult and more complex. This helps teachers develop their students to achieve the goals step-by-step without skipping steps. When seeing that success is easy, students will be inspired to study, and when they succeed, they will be proud of themselves and confident that they are able to learn.

In addition, it was also found that the processes of learning management methods or models implemented by teachers were not appropriately adjusted for students. There was nothing new, no diversity, and no variety of technology in use. The construction and production of medial to stimulate students to learn was rarely applied for students. In addition, teachers did not exchange their learning or create professional learning community in school leading to the development of learning management to be more effective. 
Creating Professional Learning Community is an important process that allow many teachers together to share their knowledge and ideas in designing effective learning together. Only one teacher may not have an appropriate learning management for a number of students. Therefore, creating a learning community in a school is a process that plays an important role in developing teaching and learning management for teachers.

Consequently, as an administrator of the school who plays an important role in driving the development of education in school, I realized the condition of the current problems and the needs to develop to promote and enhance learning achievement for learners, especially, in the fields of reading and writing. This is considered necessary and important foundation for learning in other subjects. Therefore, the focus is on the importance of internal supervision using the Learning Community Process to drive teacher development by collaborating in suggesting solutions to problems, developing a model of learning management methods, providing comments and suggestions, and implementing the agreement or conclusion obtained from the Learning Community Process into practice seriously to promote and support learners to have better knowledge, competence and achievement in reading and writing.

\section{METHODS}

Being provided with the model and processes of internal supervision using the Professional Learning Community process and the policy of the Office of the Basic Education Commission the organization delivering the policy to drive innovation in education to develop education to reach higher learning achievement, Ban Hua Fai School organized a Professional Learning Community activity to create the innovation that can be used to promote learning development of learners and for internal supervision of the school detailed as following steps.

a. Step 1: creating a group of Professional Learning Community

This step is to organize the meeting of teachers and staff of the school to create awareness and understanding for students' learning development together and set guidelines for systematic development by engaging the participation of teachers and all school staff to present opinions and methods in order to get guidelines for student development and get the school's Professional Learning Community group.

b. Step 2: Analyzing and identifying problems or needs of development

This step is to organize a Professional Learning Community to analyze problems using data from students' reports such as the results of the first grade reading test (RT), students' quality assessment at the grade $3(\mathrm{NT})$, the national test at the grade 6 (O-NET), and the learning achievements of all students in all subjects. Then, teachers and all staff work together to identify factors that affect the various problems. According to the data analysis through the Professional Learning Community (PLC) at Ban Hua Fai School, it was found that the problem and obstacle in learning among students was the learner's literacy. 
c. Step 3: Searching for or designing innovation to solve problem

This step was organizing a Professional Learning Community (PLC) to explore how to help solve problems and promote the development of students' reading and writing by assigning all teachers to invent or investigate methods in order to be critiqued and selected as school innovations.

d. Step 4: Discussing and selecting innovation to solve problems

This step is to organize a Professional Learning Community in order to consider the appropriateness of the innovations or methods from each member and the possibility to fix the problem. Based on the opinions suggested by teachers, it was found that the innovation for teaching basic words using the 6-step teaching technique by Sirilak Chompookham was an effective technique for developing students' literacy. However, there were some steps inappropriate for the context of the school, Ban Hua Fai School decided to choose the 6-steps teaching technique by Sirilak Chomphamkham as a guideline along and improve the innovation through the Professional Learning Community together. Finally, the innovation for teaching basic words based on 6-steps teaching technique of Ban Hua Fai School was formed.

e. Step 5: Try out using the innovation for teaching and learning management

In this step, teachers applied the innovation into lesson plans in order to try out using the innovation in classroom. The teaching records of each teachers were collected to reflect the results of teaching through the Professional Learning Community (PLC).

f. Step 6: Assessment of innovation implementation and development

In this step, the results of each teacher's teaching and learning management were gathered up to reflect the strengths and weaknesses needed to be improved for the innovation. Everyone took part to improve the methods of teaching and learning to be suitable for students and more efficient. Thus, the innovation of teaching techniques using a 6-steps teaching technique of Ban Hua Fai School was successfully created.

\section{RESULT AND DISCUSSION}

For Ban Hua Fai School, after selecting a 6-steps teaching technique as a guideline to solve students' illiteracy problem, all staff joined together in the review session by using the Professional Learning Community (PLC) process to analyze and design a new 6-steps teaching process in accordance with the context of the students of Ban Hua Fai School as follows:

a. Step 1: Practice reading basic words.

b. Step 2: Practice writing basic words along with dictation.

c. Step 3: Practicing writing basic word.

d. Step 4: Telling the relationship between pictures and words classified into following classes:

- Grades 1-3: Draw a line linking the relationship between basic words and pictures.

- Grade 4-6: Fill in basic words that match with the pictures, then classify the 
basic words.

e. Step 5: Compose communication sentences from basic words (positive sentences, negative sentences and interrogative sentences).

f. Step 6: Write a simple imaginary story from basic words.

The processes of internal supervision using Professional Learning Community (PLC) of Ban Hua Fai School

a. Planning. The detailed record of internal supervision of the school was prepared, the school informed the staff with the notification on appointment of innovation creation as well as the notification on appointment of internal supervision, working calendar for internal supervision, and calendar for internal supervision committee.

b. Acting. The school held the workshop to provide the teachers the details of internal supervision records and the design of lesson plan for basic word learning for each class level through professional learning community (PLC) activity. This is to obtain the lesson plan that meets the need of each class level to be used by the teacher in that level. After that, each teacher created their own lesson plan to teach basic words for their students in their class level as well as prepare materials for teaching basic words.

c. Observing. In this stage, teachers observe teaching and learning and the use of media or materials in classroom for reading and writing basic words in each class level according to the internal supervision calendar.

d. Reflecting. After observing teachers' teaching management in each class, teachers inform their students the results of learning, strengths and weaknesses needed to be developed for teaching and learning management in order to improve the development of teaching management.

e. Outcomes after finishing the operation processes

i. Classroom Level

1. Students had a higher level of development in reading and writing.

2. Students learn potentially and happily and were more interested in learning.

3. Teachers applied the new appropriate innovation to be used in classroom to increase the efficiency of learning management.

4. Teachers improved and developed teaching methods, using materials for teaching, and producing interesting teaching media regularly.

ii. School Level

1) Administrators and teachers obtained knowledge and understanding processes of participatory working called PLC. Staff of school or educational institutes loved and appreciated working together to enhance happy working atmosphere and good relationship. 
2) There was a development of working in team to build up strong teamwork and enhance efficiency and effective operation.

\section{CONCLUSIONS AND SUGGESTIONS}

The operation of internal supervision using the Professional Learning Community (PLC) process was performed to develop students' reading and writing abilities with the 6steps teaching technique of Ban Hua Fai School. It was generated from the effort in which the school pushed up in order to search for good, effective, and appropriate teaching method that fit into the context of the students in the school so that the method or innovation can be applied for developing the students to have higher competent. The results of the operation can be summarized as follows.

a. Aspect of student: Students were able to read and write, and their learning achievement increased from pre-test and the post-test scores after learning sets of basic words in each unit increased. The students' desirable characteristics according to the curriculum B.E.2551 that focuses on students' knowledge, morality, Reading Test ( $\mathrm{T}$ ) scores of Prathomsuksa 1 in academic year 2020 in both reading abilities were 23.11 percent higher than 2019. The results of the learner quality assessment (NT) of Prathomsuksa 3 students in the academic year 2020 showed that the average score in Thai language was $4.20 \%$ higher than the academic year 2019 .

b. Aspect of teachers and school staff: Teachers were more knowledgeable capable of organizing teaching activities. They obtained knowledge and understanding of internal supervision processes, recognized the importance of internal supervision, and there was a learning exchange through the Professional Learning Community to develop teaching and learning approach together. In addition, they also participated in internal supervision and had a better relationship with each other, and became good role models with honorable appreciation.

c. Aspect of school: The school developed the internal supervision systematically along with a Professional Learning Community group leading to move the innovation forward and to develop teaching and learning methods to be more effective. The school was recognized and trusted by parents and community for taking care of students, and obtained credibility in educational management.

d. Aspect of Community: The school was credible and trusted by parents and community to improve school education. Parents were confident in the school learning management for their students.

e. Aspect of school administrators: The school administrators performed themselves as good leaders in developing school education, leading teachers to drive internal supervision operation using the Professional Learning Community process to develop students' reading and writing skills to their fullest and capacity under the participatory operation of teachers and all personnel in the school. 


\section{REFERENCES}

Basic Education, Office of the Commission. (2005). Assessment of reading, thinking, analyzing, and writing according to the curriculum B.E. 2544. Bangkok : Express Transportation Organization.

Kannipha Brahminphithak. (2010). Learning Management to success in adopting curriculum into the Classroom. Academic Journal, 13 (1), 63-65.

Rattana Nakhonthep. (2009). Presentation of internal supervision model by applying Kalyanamit Model in basic educational institutions. Ubon Ratchathani Educational Service Area Office 2. Master of Education Thesis. Ubon Ratchathani University.

Thitsana Khamanee. (2002). Teaching Science - Knowledge for Organizing an Effective Learning Process. (2nd Edition). Bangkok : Dansuuttha Printing.

Woraluck Chookamnoed. (2014). School of Professional Learning Community of Teaching Profession focusing on Learner-Centered. Academic Service Journal, 25(1), 93-102. 